\title{
ASSESSMENT OF CYTOKINE VALUES IN SERUM BY RT-PCR IN HIV-1 INFECTED INDIVIDUALS WITH AND WITHOUT HIGHLY ACTIVE ANTI-RETROVIRAL THERAPY (HAART)
}

\section{MEIRA DA (1), ALMEIDA RAMB (1), BARBOSA AN (1), DE SOUZA LR (1), OLIVO TET (1), HENRIQUES RMS (1), GOLIM MA (1), ARAÚJO JR JP (2), NAGOSHI LR (1), ORIKAZA CM (1), CALVI SA (1)}

(1) Department of Tropical Diseases, Botucatu Medical School, São Paulo State University, UNESP, Botucatu, São Paulo State, Brazil; (2) Department of Microbiology and Immunology, Botucatu Bioscience Institute, São Paulo State University, UNESP, Botucatu, São Paulo State, Brazil.

ABSTRACT: A cross-sectional study was performed on HIV-1 infected individuals with or without antiretroviral treatment (ARV) in the AIDS Day Hospital, Botucatu Medical School, UNESP. Between August 2004 and October 2005, 73 HIV-1 infected individuals were divided into three groups: infected individuals with or without AIDS who had never received ARV $\left(G_{1}\right.$ = 15); patients on HAART that had had plasma HIV-1 RNA viral load (VL) equal to or greater than 50 copies/mL $\left(\mathrm{G}_{2}=27\right)$; and patients on HAART with undetectable VL for at least the past six months $\left(\mathrm{G}_{3}=31\right)$. There was also an additional group that comprised blood donors without any sign of the disease and with negative HIV serum tests $\left(G_{4}=20\right)$, which was the control group. Serum cytokine levels (values in $\mathrm{pg} / \mathrm{mL}$ ) were measured by enzyme-linked immunosorbent assay (ELISA) and specific mRNA expression by reverse transcription polymerase chain reaction (RT-PCR). Both techniques were performed on the four groups for TNF- $\alpha$, IL-2, INF- $\gamma$, IL-4 and IL-10. All patients were submitted to VL determination and $\mathrm{CD}^{+}$and $\mathrm{CD}^{+} \mathrm{T}$ lymphocyte counts. The analysis of the results revealed a significant comparison among groups for both methods and an association between the latter $>80 \%-$ $\left.r^{2}>0.80\right)$. There was only one exception, in control individuals for IL-2 by ELISA. The cytokine profiles, in both methods, for the three patient groups, were mature Th-0. The behaviors of IL-2 and INF- $\gamma$ required emphasis due to consequent expression of dominant Th profile. Both methods showed low IL-2 and high mean values of INF- $\gamma$ in the three groups. Several authors have recently drawn attention to the substantial apoptosis of infected and non-infected $\mathrm{CD} 4^{+} \mathrm{T}$ cells, mainly during primary infection, persisting only in those with INF$\gamma$ phenotype producer and not IL-2. HIV infected individuals submitted to HAART are expected to produce IL-2 in an attempt to present Th-1 profile, but in most cases this did not occur.

KEY WORDS: RT-PCR, ELISA, cytokines, HIV, AIDS, HAART, apoptosis.

CONFLICTS OF INTEREST: There is no conflict.

FINANCIAL SOURCE: FAPESP.

TRIAL REGISTRATION NUMBER: NCT00746473 in the Clinical Trials.gov.

CORRESPONDENCE TO:

DOMINGOS ALVES MEIRA, Departamento de Doenças Tropicais e Diagnóstico por Imagem, Faculdade de Medicina de Botucatu, UNESP, Distrito de Rubião Júnior s/n, Botucatu, SP, 18618-000, Brasil. Phone: +55 1438116212 . Fax: +55 1438159898.

Email: d.meira@uol.com.br. 
D. A. Meira et al. ASSESSMENT OF CYTOKINE VALUES IN SERUM BY RT-PCR IN HIV-1 INFECTED INDIVIDUALS WITH AND WITHOUT HIGHLY ACTIVE ANTI-RETROVIRAL THERAPY (HAART). J. Venom. Anim. Toxins incl. Trop. Dis., 2008, 14, 4, p. 686

\section{INTRODUCTION}

Highly active anti-retroviral therapy (HAART) causes important interference in the natural history of HIV-1 infection. Haase (9) reported the impact of this treatment on suppressing viral replication that could be observed by VL determination. However, even with this vigorous action, the treatment did not completely eliminate the virus. Pierson et al. (20), considering the half-life of latently infected cells which are HIV-1 reservoirs, applied a mathematical model and concluded that more than 60 years of treatment would be required to eradicate this compartment. Regarding HIV surrogate markers, VL has been of great use, as the reduction in number of RNA copies per $\mathrm{mL}$ of plasma, often not detectable, has become an eloquent indicator of therapeutic action. The clinical evolution of concomitant patients shows increased survival, easier control of opportunistic infections, and a reduction in the number of deaths for patients under treatment (16). According to Gougeon et al. (7) the other surrogate marker, represented by $\mathrm{CD} 4^{+} \mathrm{T} / \mathrm{mm}^{3}$, which can give information on suppression level or immune system recovery level in patients under treatment, is influenced by complex mechanisms with complicate interpretation. Carcelain et al. (2), discussing immune reconstitution during HIV infection under HAART, mentioned three mechanisms involved in $\mathrm{CD}^{+} \mathrm{T}$ lymphocyte recuperation, which are: redistribution of memory $C D 4^{+} \mathrm{T}$ cells from tissues where they have been previously sequestered; regeneration of virgin thymus cells; and reduction of inflammatory process. In this manner, $C D 4^{+} \mathrm{T}$ count does not reflect the real number of virgin, memory, or recirculating $\mathrm{CD}^{+} \mathrm{T}$ cells after the reduction of therapeutic viral replication. Additionally, quantitative evaluation of these cells does not inform us which cytokines they are producing. Haase (9), referring to naïve $C D 4^{+} \mathrm{T}$ cell repopulation during treatment, mentioned that they slowly increase, but only many months after therapy introduction. According to the latter author, immunity regeneration is slow, variable and partial.

The main problem concerning HIV-1 infected individuals, when they are submitted to HAART, is the evaluation of immune function under this therapy interference. It is necessary to search for other markers to notice whether or not there is immunological recovery $(4,5)$. Cytokine levels and the knowledge of their respective profiles can be evolution markers of immune response during ARV treatment. 
D. A. Meira et al. ASSESSMENT OF CYTOKINE VALUES IN SERUM BY RT-PCR IN HIV-1 INFECTED INDIVIDUALS WITH AND WITHOUT HIGHLY ACTIVE ANTI-RETROVIRAL THERAPY (HAART). J. Venom. Anim. Toxins incl. Trop. Dis., 2008, 14, 4, p. 687

Clerici and Shearer (3), in 1993, were the first to propose the use of cytokines as progression markers for AIDS, which can be indicated by a drop in IL-2 and INF- $\gamma$ and a concomitant increase in IL-4 and IL-10. Meira et al. $(14,15)$, in previous publications, demonstrated the importance of cytokines as evolution markers, mainly regarding HAART. Imami et al. (11), in 1999, studied Th-1/Th-2 cytokine profiles in nine HIV patients before and during HAART by amplification and detection of specific cDNA, using real-time PCR. They suggested that the determination of cytokine profiles in HIV-1 in these two periods could complement information from VL and $\mathrm{CD}^{+} \mathrm{T} / \mathrm{mm}^{3}$ cell count (11). This permitted to verify how the treatment affected the immune recovery in these patients.

The objectives of the current study were: to evaluate the role of serum cytokines levels (TNF- $\alpha$, INF- $\gamma$, IL-2, IL-4, and IL-10) and mRNA expression by real-time PCR, compare these two methods and examine Th-1, mature Th-0, and Th-2 cytokine profiles. Therefore, a cross-sectional study was employed to analyze three patient groups: "treatment virgins"; HAART with detectable VL; and HAART without detectable VL.

\section{PATIENTS AND METHODS}

\section{Patients}

Between August 2004 and October 2005, 73 HIV-1 infected individuals, ill and not ill, were monitored at the Specialized Outpatient Service and Day Hospital for AIDS patients, part of the medical complex of Botucatu Medical School, UNESP. All persons had a history compatible with HIV-1 infection, with either positive ELISA or Western blot. Among them, 38 were female and 35 male and their ages ranged from 22 to 66 years old (mean: 40 years). Twenty normal blood donors from the Botucatu Hemocenter were also included, 16 were male and four female and aged between 19 and 62 years old (mean: 37 years).

\section{Methods}

\section{- Groups}

Group $1\left(G_{1}\right)$ : 15 HIV-1 infected individuals, with or without AIDS, who had never received ARV. These patients had not yet been indicated for ARV, or had had HIV-1 infection diagnosed a few days before inclusion in the present study. Individuals from 
D. A. Meira et al. ASSESSMENT OF CYTOKINE VALUES IN SERUM BY RT-PCR IN HIV-1 INFECTED INDIVIDUALS WITH AND WITHOUT HIGHLY ACTIVE ANTI-RETROVIRAL THERAPY (HAART). J. Venom. Anim. Toxins incl. Trop. Dis., 2008, 14, 4, p. 688

this group were the only ones who were not on ARV treatment, thus could be considered as representatives of the natural history of HIV infection. Patients in the other two groups were under the influence of treatment.

Group $2\left(\mathrm{G}_{2}\right)$ : 27 HIV-1 infected individuals, sick or not, on ARV treatment, five with two nucleoside/nucleotide reverse transcriptase inhibitors (NRTI) and one nonnucleoside reverse transcriptase inhibitor (NNRTI); and 22 on HAART with two NRTI, or one NRTI and one NNRTI, and one protease inhibitor (PI), and VL equal to or greater than 50 copies of plasma RNA/mL.

Treatment duration in this group varied between three and 145 months (mean: 53.6 months; median: 42 months).

Group $3\left(\mathrm{G}_{3}\right)$ : 31 HIV-1 infected individuals on ARV treatment, 16 on HAART with two $\mathrm{NRTI}$, or one NRTI and one NNRTI, and one PI, and 15 with two NRTI and one NNRTI. All $G_{3}$ patients had undetectable $V L$ for at least the past six months. Treatment in this group varied between five and 108 months (mean: 48.1 months; median: 42 months). In both groups $G_{2}$ and $G_{3}$, all individuals were under $A R V$ treatment and classified as positive $\left(G_{2}\right)$ or undetectable $\left(G_{3}\right)$ VL, which indicates a clear distinction between them concerning viral activity and, consequently, presents an important factor that must be considered for the interpretation of HIV-1 pathogenicity (12).

Group $4\left(\mathrm{G}_{4}\right)$ : 20 blood donors without any clinical complaints and negative for antiHIV-1/2 antibodies. None of them presented any sign of the disease.

\section{Parameters considered}

\section{- Clinical parameters}

All 73 infected individuals were submitted to clinical observation that included HIVassociated opportunistic diseases at the time of blood collection for cytokine detection.

\section{- Laboratorial parameters}

The 73 persons $\left(G_{1}, G_{2}\right.$, and $\left.G_{3}\right)$ were submitted at same time to: $V L$ determination; $\mathrm{CD}^{+} \mathrm{T}$ and $\mathrm{CD}^{+} \mathrm{T} / \mathrm{mm}^{3}$ lymphocyte count; and TNF- $\alpha$, INF- $\gamma, \mathrm{IL}-2, \mathrm{IL}-4$ and IL-10 serum cytokine determination by amplification and detection of cytokine-specific cDNA through RT-PCR. 
D. A. Meira et al. ASSESSMENT OF CYTOKINE VALUES IN SERUM BY RT-PCR IN HIV-1 INFECTED INDIVIDUALS WITH AND WITHOUT HIGHLY ACTIVE ANTI-RETROVIRAL THERAPY (HAART). J. Venom. Anim. Toxins incl. Trop. Dis., 2008, 14, 4, p. 689

\section{- HIV-1 plasma viral load determination}

Infected individuals were tested for HIV-1 plasma VL by the bDNA HIV-1 RNA QT system. The low limit for detection by this method was considered 50 copies $/ \mathrm{mL}$.

\section{- $\mathrm{CD}^{+} \mathrm{T}$ and $\mathrm{CD8}{ }^{+} \mathrm{T} / \mathrm{mm}^{3}$ lymphocyte counts}

The numbers of $\mathrm{CD}^{+}$and $\mathrm{CD} 8^{+} \mathrm{T}$ cells were measured from all HIV-infected patients in $G_{1}, G_{2}$, and $G_{3}$ using four-color flow cytometry and the commercially available Multitest IMK® kit (Becton Dickinson, USA) (13).

\section{- Serum cytokine determination}

We collected $8 \mathrm{~mL}$ of blood, in a dry tube, from $73 \mathrm{HIV}-1\left(\mathrm{G}_{1}, \mathrm{G}_{2}\right.$, and $\left.\mathrm{G}_{3}\right)$ and 20 normal $\left(G_{4}\right)$ individuals. The serum was immediately separated, aliquoted and stored at $-70^{\circ} \mathrm{C}$. Serum cytokine determination was performed between four and 12 weeks after storage. TNF- $\alpha$, INF- $\gamma$, IL-2, IL-4 and IL-10 cytokines were determined by ELISA, with Human Quantikine $\circledR$ kits (R\&D Systems, USA). Initially, 96 microplates were sensitized with anti-cytokine monoclonal antibody (TNF- $\alpha$, INF- $\gamma$, IL-2, IL-4 and IL-10). Subsequently, $200 \mu \mathrm{L}$ of test serum, positive and negative controls, was added (dilution 1:2) to the samples that, afterwards, were incubated at $37^{\circ} \mathrm{C}$ for periods ranging from 30 to 60 minutes, depending on the cytokine. Four washes were carried out with detergent solution containing 2-chloroacetamide $(0.1 \%)$. This was repeated until the phase preceding substrate addition. Then, biotin marked plates received streptavidin-peroxidase. After incubation, a substrate containing hydrogen peroxide $(0.02 \%)$ and tetramethylbenzene $(2 \%)$ was added. The reaction was interrupted at room temperature with $2 \mathrm{~N}$ sulfuric acid. Results were evaluated by optical density (OD) on a Multiskan analyser (EFLAB, Finland) reader at $450 \mathrm{~nm}$. Serum cytokine concentrations were calculated from a standard curve $(15,17)$. The detection limits of serum cytokines were 15.6 to $1,000 \mathrm{pg} / \mathrm{mL}$ for TNF- $\alpha$ and IFN- $\gamma$, 31.2 to $2,000 \mathrm{pg} / \mathrm{mL}$ for IL-2, 1.6 to $5,000 \mathrm{pg} / \mathrm{mL}$ for IL-4 and 3.2 to $10,000 \mathrm{pg} / \mathrm{mL}$ for IL-10.

- Cytokine dosage by amplification and specific cDNA detection using realtime PCR

Peripheral blood mononuclear cells (PBMC) were obtained from heparinized blood by means of standard Histopaque-1077® (Sigma-Aldrich, USA) gradient centrifugation (1). Total RNA was extracted from PBMC immediately after the collection utilizing Trizol $®$ reagent (Invitrogen, USA) according to manufacturer 
D. A. Meira et al. ASSESSMENT OF CYTOKINE VALUES IN SERUM BY RT-PCR IN HIV-1 INFECTED INDIVIDUALS WITH AND WITHOUT HIGHLY ACTIVE ANTI-RETROVIRAL THERAPY (HAART). J. Venom. Anim. Toxins incl. Trop. Dis., 2008, 14, 4, p. 690

instructions. DNase digestion of RNA solution was carried with DNase (RQ1 RNaseFree DNase $\AA$, Promega, USA). The Platzer and Blankestein (21) technique was employed to obtain CDNA. Semi-quantitative RT-PCR was performed in real time (7300 Real Time PCR System®, Applied Biosystems, USA) using Lux primers (Certified Lux ${ }^{\circledR}$ Primer Set, Invitrogen, USA) for the following cytokines: IL-2 (GenBank accession number NM 000586); IL-4 (GenBank accession number NM 000589); IL-10 (GenBank accession number NM 000572); INF- $\gamma$ (GenBank accession number NM 000619); and TNF- $\alpha$ (GenBank accession number NM 000594); $\beta$-actin (GenBank accession number NM 001101-2) - used for housekeeping reactions. Platinum PCR Supermix $®$ (Invitrogen, USA) was utilized for the PCR reaction. Samples were distributed on 96-well plates and amplified in real time under the following incubation conditions: 2 minutes at $50^{\circ} \mathrm{C}$ and $95^{\circ} \mathrm{C}, 45$ cycles at $95^{\circ} \mathrm{C}$ for 15 seconds, $55^{\circ} \mathrm{C}$ and $72^{\circ} \mathrm{C}$ for 30 seconds during which fluorescence data were obtained. The threshold cycle $(\mathrm{Ct})$ reflects the cycle number at which the fluorescence generated within a reaction cross the threshold. The $\mathrm{Ct}$ value assigned to a particular well thus reflects the point during the reaction at which a sufficient number of amplicons have accumulated, in that well, to be at a statistically significant point above the baseline (18). One member of the normal group $\left(G_{4}\right)$ was randomly selected for serial dilutions of cDNA, which was used as a standard cytokine quantification reference. Results expressed as $C$ t values for $\beta$-actin and cytokines, for each individual, were corrected based on values from the normal individual according to the standard real-time calculation.

\section{- Statistical analysis}

Mean $(\bar{X})$, standard deviation (SD) and median (Md) were calculated for each group. Comparison among groups $G_{1}, G_{2}, G_{3}$ and $G_{4}$ - regarding serum cytokines, amplification and detection of specific cDNA - was made by non-parametric KruskalWallis test (26), with $\mathrm{H}$ and $\mathrm{p}$ statistics (chi-square distribution) and considering differences between group means $(p<0.05)$. Similarity between ELISA and RT-PCR methods was studied by linear correlation coefficient between two measurements and after the linear regression equation $Y=f(X)$, where $Y=R T-P C R$ and $X=$ ELISA, with the respective coefficient of determination $\left(r^{2}\right)$. A correlation was considered significant when $r^{2}>0.60$ and high when $r^{2}>0.80 . \mathrm{CD}^{+} T$ and $\mathrm{CD} 8^{+} \mathrm{T} / \mathrm{mm}^{3}$ lymphocyte counts and $\mathrm{VL}$ determination values (by non-parametric 
D. A. Meira et al. ASSESSMENT OF CYTOKINE VALUES IN SERUM BY RT-PCR IN HIV-1 INFECTED INDIVIDUALS WITH AND WITHOUT HIGHLY ACTIVE ANTI-RETROVIRAL THERAPY (HAART). J. Venom. Anim. Toxins incl. Trop. Dis., 2008, 14, 4, p. 691

Kruskal-Wallis test) were compared among groups $G_{1}, G_{2}$ and $G_{3}$ (26). Serum and real-time PCR cytokine normal values were obtained by $\bar{X}+1 \mathrm{SD}$ of their respective values from the control group $\left(\mathrm{G}_{4}\right)(26)$. Thus, Th-1, mature Th- 0 and Th-2 subsets were defined by their normal values according to Spellberg and Edwards (22). These authors considered mature Th- 0 profile in situations where the $C D 4^{+} \mathrm{T}$ cells produced elevated levels of INF- $\gamma$ and IL-4. Other authors have also reported Th-0 profile $(6,8$, 19). The proportions of $\mathrm{PI}$ regimens in $\mathrm{G}_{2}$ and $\mathrm{G}_{3}$ and treatment duration in each group submitted to HAART $\left(\mathrm{G}_{2}\right.$ and $\left.\mathrm{G}_{3}\right)$ were compared by the $\chi^{2}$ (chi-square) test (26).

\section{RESULTS}

\section{HAART}

\section{- ARV treatment scheme}

Twenty-two patients from $\mathrm{G}_{2}$ received protease inhibitors associated with two NRTI or one NNRTI and one NRTI. The other five patients in this group were treated with two NRTI and one NNRTI. Sixteen $\mathrm{G}_{3}$ patients received protease inhibitors associated with two NRTI or one NNRTI and one NRTI. The other fifteen received two NRTI and one NNRTI. There was statistical difference between groups in relation to protease inhibitor $\left(\chi_{1}^{2}=6.99 ; p<0.01 ; \mathrm{G}_{2}>\mathrm{G}_{3}\right)$.

\section{- Treatment duration}

Comparison between treatment groups showed no statistical difference with respect to duration. Seventeen $G_{2}$ patients were treated for a period of three to 60 months and the other ten, for a period of 61 to 145 months. Twenty-two $\mathrm{G}_{3}$ patients were treated for three to 60 months and the other nine, for 61 to 145 months $\left(\chi^{2}{ }_{1}=0.41\right.$; not significant).

\section{$\mathrm{CD4}^{+}$and $\mathrm{CD}^{+} \mathrm{T}$ lymphocyte counts}

Median (Md), mean ( $\bar{X})$ and standard deviation (SD) values of $\mathrm{CD}^{+} \mathrm{T}$ lymphocytes $/ \mathrm{mm}^{3}$ in the patient groups were:

$$
\begin{aligned}
& -\mathrm{G}_{1}: \mathrm{Md}=313 ; \bar{X}=383 ; \text { and } \mathrm{SD}=229 \\
& -\mathrm{G}_{2}: \mathrm{Md}=334 ; \bar{X}=334 ; \text { and } \mathrm{SD}=186 ; \\
& -\mathrm{G}_{3}: \mathrm{Md}=419 ; \bar{X}=470 ; \text { and } \mathrm{SD}=247
\end{aligned}
$$


D. A. Meira et al. ASSESSMENT OF CYTOKINE VALUES IN SERUM BY RT-PCR IN HIV-1 INFECTED INDIVIDUALS WITH AND WITHOUT HIGHLY ACTIVE ANTI-RETROVIRAL THERAPY (HAART). J. Venom. Anim. Toxins incl. Trop. Dis., 2008, 14, 4, p. 692

Comparison between groups showed no statistical difference $(H=4.371 ; p>0.10$; $\mathrm{G}_{1}=\mathrm{G}_{2}=\mathrm{G}_{3}$ ). Median (Md), mean $(\bar{X})$ and standard deviation (SD) values of $\mathrm{CD}^{+} \mathrm{T}$ lymphocytes $/ \mathrm{mm}^{3}$ were:

- $\mathrm{G}_{1}: \mathrm{Md}=739 ; \bar{X}=951 ;$ and $\mathrm{SD}=619$;

- $\mathrm{G}_{2}: \mathrm{Md}=777 ; \bar{X}=886$; and $\mathrm{SD}=473$;

- $\mathrm{G}_{3}: \mathrm{Md}=729 ; \bar{X}=745 ;$ and $\mathrm{SD}=315$.

Comparison between groups showed no statistical difference $(H=1.281 ; p>0.10$; $\left.\mathrm{G}_{1}=\mathrm{G}_{2}=\mathrm{G}_{3}\right)$.

\section{VL behavior}

$V L$ mean for $G_{1}$ patients was 31,231 copies $/ \mathrm{mL}\left(\log 4.49\right.$ ), and for $G_{2}$ patients was 8,779 copies $/ \mathrm{mL}(\log 3.94)$.

\section{Comparison and correlation of cytokine levels in serum (ELISA) and by amplification and specific cDNA detection using real-time PCR (RT-PCR)}

Figure 1 shows the distribution of cytokine values (TNF- $\alpha$, INF- $\gamma$, IL-2, IL-4 and IL-10) obtained through serum dosage by ELISA. The graph shows individual values for each cytokine and the horizontal line in each column refers to the median values obtained from the respective study group. Analysis of this figure suggests that TNF- $\alpha$ values decrease in the comparison among patient groups $\left(G_{1}\right.$ to $\left.G_{3}\right)$, but remain elevated in relation to controls $\left(G_{4}\right)$. The drop may be due to the antiretroviral treatment in $G_{2}$ and $G_{3}$. INF- $\gamma$ presented opposite behavior and increased from $G_{1}$ to $\mathrm{G}_{3}$, which could also be due to the antiretroviral treatment. IL-2 however, remained low, not differing from normal values $\left(\mathrm{G}_{4}\right)$, and presented the same median level in the four groups. This fact could be associated with a possible incapacity of $\mathrm{CD} 4^{+} \mathrm{T}$ cells, in HIV-1 infected individuals, to produce IL-2, even in patients under treatment or with undetectable VL. The latter finding suggests that a potent combined antiretroviral treatment is effective as it improves the life condition of patients, permits better control of opportunistic infections and increases survival in infected individuals. However, this type of treatment is not completely efficacious, since incapacity to perform HIV-1 clearance, or increase IL-2 production, suggests an inability to induce adaptive immune recovery. 


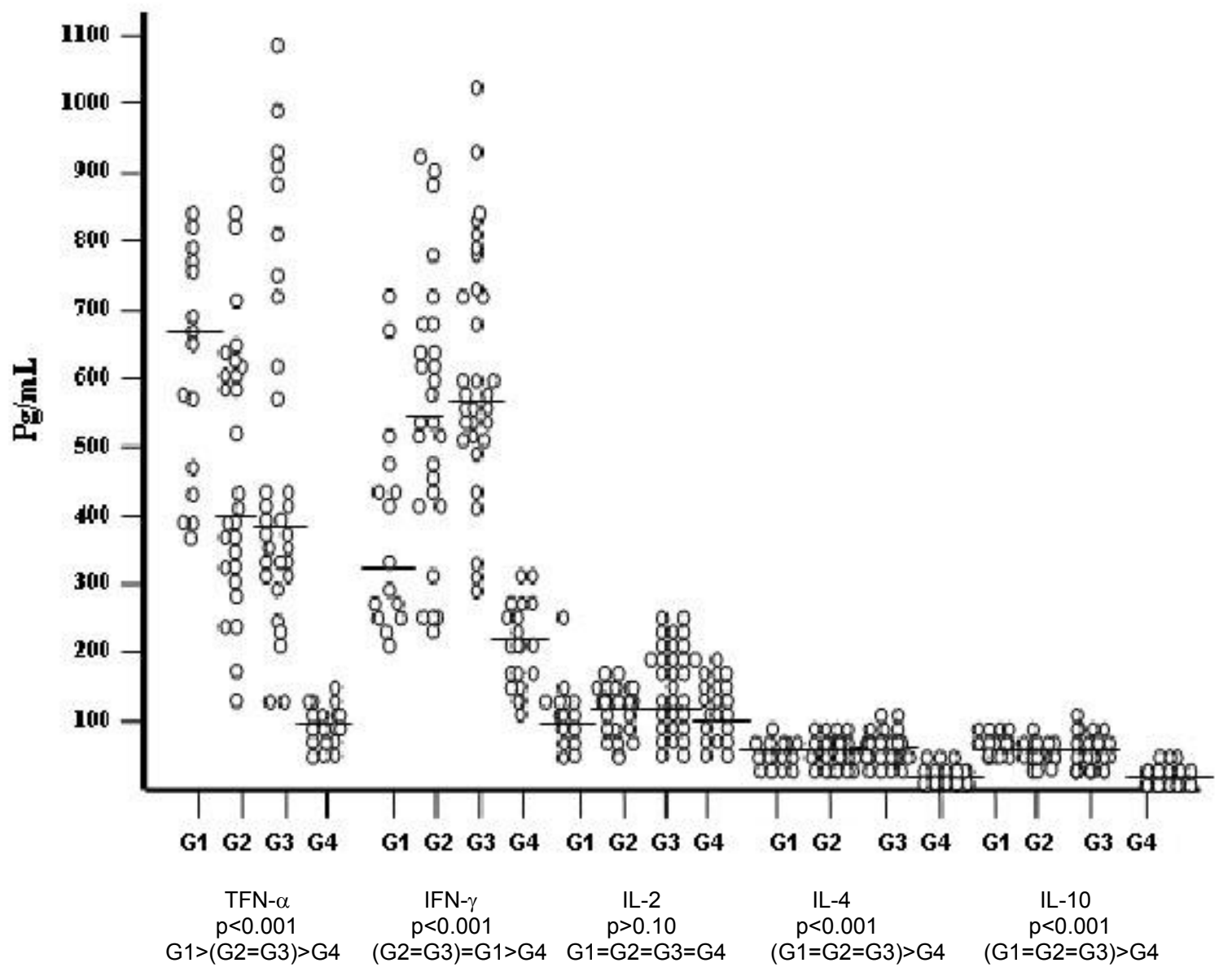

Figure 1. Distribution of serum cytokine values per group (ELISA).

$=$ median

G1: 15 HIV-1 patients virgin to treatment; G2: 27 HIV-1 patients under HAART with detectable VL; G3:

31 HIV-1 patients under HAART with undetectable VL; G4: 20 normal blood donor volunteers.

Figure 2 presents cytokine level distribution in mononuclear cells by RT-PCR. Median values of TNF- $\alpha$ and INF- $\gamma$ for each group $\left(G_{1}\right.$ to $\left.G_{3}\right)$ show a similar behavior to Figure 1 , which reveals similarity between both methods (ELISA and RT-PCR). There was a small increase in IL-2 levels in treatment virgin patients $\left(G_{1}\right)$ when compared to persons under treatment that presented detectable $V L\left(G_{2}\right)$, while there was a decrease in individuals under treatment with undetectable $V L\left(G_{3}\right)$. Statistical 
D. A. Meira et al. ASSESSMENT OF CYTOKINE VALUES IN SERUM BY RT-PCR IN HIV-1 INFECTED INDIVIDUALS WITH AND WITHOUT HIGHLY ACTIVE ANTI-RETROVIRAL THERAPY (HAART). J. Venom. Anim. Toxins incl. Trop. Dis., 2008, 14, 4, p. 694

analysis revealed that IL-2 values were equal in these groups. In this sense, IL-2 behavior was the same in both measurement methods, which displays an association between them. If its behavior in patients is judged, there is no desirable IL-2 production even with antiretroviral treatment and when $\mathrm{VL}$ is reduced.

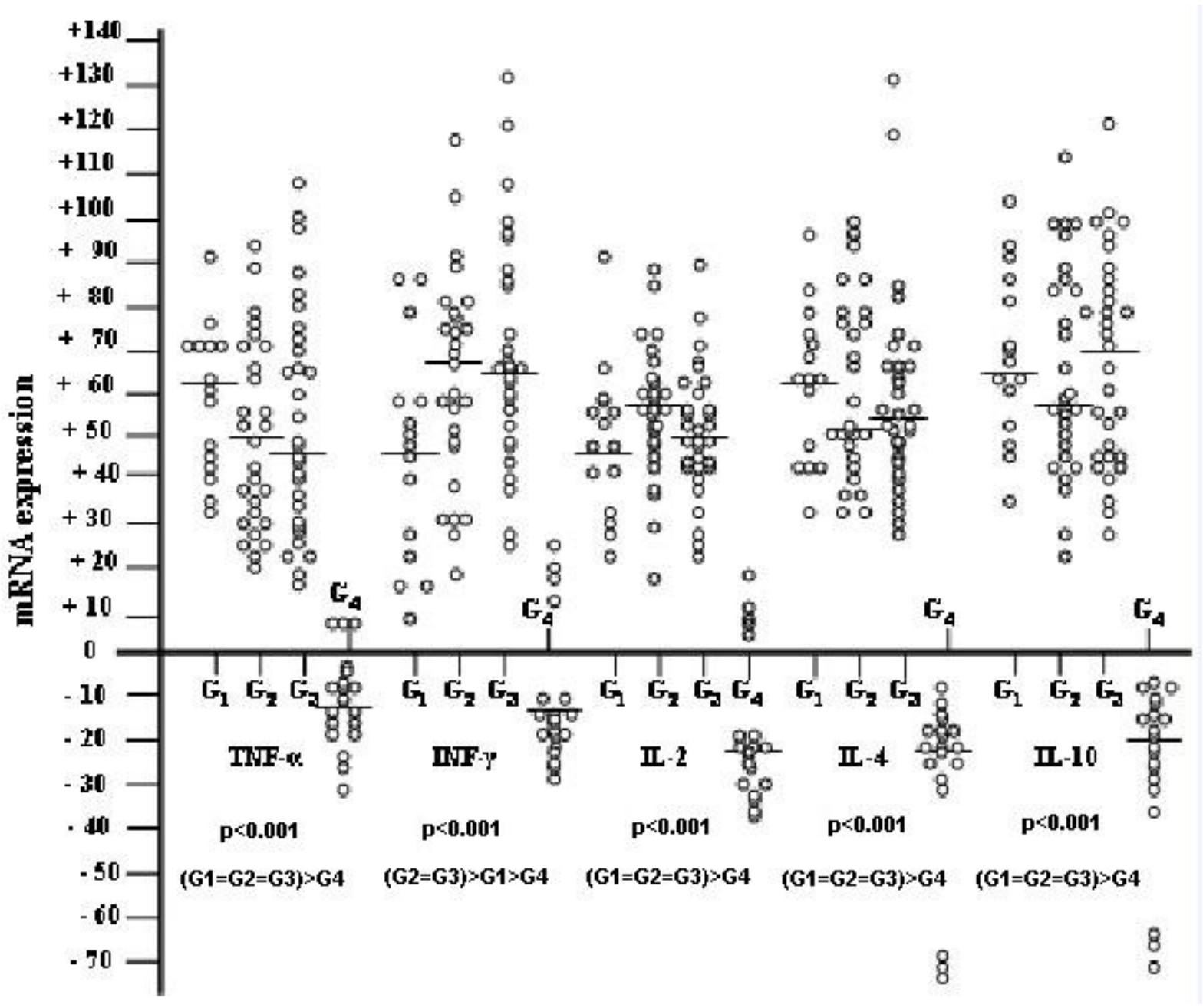

Figure 2. Distribution of mononuclear cell cytokine values per group (RT-PCR).

$=$ median

G1:15 HIV-1 patients virgin to treatment; G2: 27 HIV-1 patients under HAART with detectable VL; G3:

31 HIV-1 patients under HAART with undetectable VL; G4: 20 normal blood donor volunteers. 
D. A. Meira et al. ASSESSMENT OF CYTOKINE VALUES IN SERUM BY RT-PCR IN HIV-1 INFECTED INDIVIDUALS WITH AND WITHOUT HIGHLY ACTIVE ANTI-RETROVIRAL THERAPY (HAART). J. Venom. Anim. Toxins incl. Trop. Dis., 2008, 14, 4, p. 695

Table 1 demonstrates the statistical results from the comparison among groups regarding cytokine levels by both methods (ELISA and RT-PCR). Groups were compared by analysis of variance using the non-parametric Kruskal-Wallis method. All values show statistical significance, except for IL-2 by ELISA. This method was chosen the most consistent and, therefore most rigorous, mainly because there was no normal serum cytokine values determined by RT-PCR (26).

Table 1. Comparison and correlation of cytokine values in serum (ELISA) and in mononuclear cells (RT-PCR) in HIV-1 infected patients and normal individuals distributed into groups

\begin{tabular}{|c|c|c|c|c|c|}
\hline \multicolumn{6}{|c|}{ Statistics } \\
\hline \multirow{2}{*}{ CYTOKINES } & \multicolumn{2}{|c|}{ Calculated } & Significance & \multicolumn{2}{|c|}{ Comments } \\
\hline & ELISA & RT-PCR & ELISA RT-PCR & ELISA & RT-PCR \\
\hline TNF- $\alpha$ & $H=49.897$ & $\mathrm{H}=47.737$ & $p<0.001 p<0.001$ & $\mathrm{G}_{1}>\left(\mathrm{G}_{2}=\mathrm{G}_{3}\right)>\mathrm{G}_{4}$ & $\left(\mathrm{G}_{1}=\mathrm{G}_{2}=\mathrm{G}_{3}\right)>\mathrm{G}_{4}$ \\
\hline INF- $\gamma$ & $H=47.678$ & $H=49.614$ & $p<0.001 \quad p<0.001$ & $\left(G_{2}=G_{3}\right)>G_{1}>G_{4}$ & $\left(G_{2}=G_{3}\right)>G_{1}>G_{4}$ \\
\hline IL-2 & $H=4.094$ & $H=49.146$ & $p>0.10 \quad p<0.001$ & $\mathrm{G}_{1}=\mathrm{G}_{2}=\mathrm{G}_{3}=\mathrm{G}_{4}$ & $\left(G_{1}=G_{2}=G_{3}\right)>G_{4}$ \\
\hline IL-4 & $H=47.658$ & $\mathrm{H}=47.231$ & $p<0.001 \quad p<0.001$ & $\left(\mathrm{G}_{1}=\mathrm{G}_{2}=\mathrm{G}_{3}\right)>\mathrm{G}_{4}$ & $\left(\mathrm{G}_{1}=\mathrm{G}_{2}=\mathrm{G}_{3}\right)>\mathrm{G}_{4}$ \\
\hline IL-10 & $H=48.066$ & $\mathrm{H}=46.845$ & $p<0.001 \quad p<0.001$ & $\left(\mathrm{G}_{1}=\mathrm{G}_{2}=\mathrm{G}_{3}\right)>\mathrm{G}_{4}$ & $\left(\mathrm{G}_{1}=\mathrm{G}_{2}=\mathrm{G}_{3}\right)>\mathrm{G}_{4}$ \\
\hline \multicolumn{6}{|c|}{ Equation: ELISA (X) / RT-PCR (Y); Y = $10.72+0.12 \mathrm{X}$} \\
\hline \multirow{2}{*}{ CYTOKINES } & \multicolumn{4}{|c|}{ Coefficient } & \\
\hline & \multicolumn{2}{|c|}{ Linear correlation } & Determination & \multicolumn{2}{|c|}{ Comments } \\
\hline TNF- $\alpha$ & \multicolumn{2}{|c|}{$r=0.93 ; \quad p<0.001$} & $r^{2}=0.87$ & \multicolumn{2}{|c|}{ Positive correlation } \\
\hline INF- $\gamma$ & \multicolumn{2}{|c|}{$r=0.89 ; \quad p<0.001$} & $r^{2}=0.79$ & \multicolumn{2}{|c|}{ Positive correlation } \\
\hline IL-2 & \multicolumn{2}{|c|}{$r=0.46 ; \quad p<0.05$} & $r^{2}=0.21$ & \multicolumn{2}{|c|}{ Weak correlation } \\
\hline IL-4 & $r=0.93 ; \quad p$ & $<0.001$ & $r^{2}=0.86$ & \multicolumn{2}{|c|}{ Positive correlation } \\
\hline $\mathrm{IL}-10$ & $r=0.91 ; \quad p$ & $<0.001$ & $r^{2}=0.82$ & \multicolumn{2}{|c|}{ Positive correlation } \\
\hline
\end{tabular}

G1: 15 HIV-1 patients virgin to treatment; G2: 27 HIV-1 patients under HAART with detectable VL; G3: 31 HIV-1 patients under HAART with undetectable VL; G4: 20 normal blood donor volunteers; r: linear correlation coefficient; $r^{2}$ : determination coefficient. 
D. A. Meira et al. ASSESSMENT OF CYTOKINE VALUES IN SERUM BY RT-PCR IN HIV-1 INFECTED INDIVIDUALS WITH AND WITHOUT HIGHLY ACTIVE ANTI-RETROVIRAL THERAPY (HAART). J. Venom. Anim. Toxins incl. Trop. Dis., 2008, 14, 4, p. 696

Both methods were studied by linear correlation between two measurements followed by linear regression, which revealed an association among almost all cytokines (except for IL-2). Consequently, ELISA and RT-PCR methods demonstrated analogous behaviors.

Tables 2 and 3 respectively display medians, means and standard deviations of cytokine values obtained in serum by both ELISA and amplification and detection of specific CDNA by RT-PCR. The tables also demonstrate the normal values obtained in the same manner (mean $+1 \mathrm{SD}$ ) from the control group $\left(\mathrm{G}_{4}\right)$ as well as the Th subset from each group.

Table 2. Distribution of serum cytokine values by group (ELISA)

\begin{tabular}{|c|c|c|c|c|c|c|}
\hline \multirow{2}{*}{ Groups } & \multicolumn{5}{|c|}{ Serum cytokines (pg/mL) } & \multirow{2}{*}{ Th subset } \\
\hline & $\begin{array}{c}\text { TNF- } \alpha \\
\mathrm{Md} / \overline{\boldsymbol{x}} / \mathrm{SD}\end{array}$ & $\begin{array}{c}\mathrm{IFN}-\gamma \\
\mathrm{Md} / \bar{x} / \mathrm{SD}\end{array}$ & $\mathrm{Md} / \frac{\mathrm{IL}-2}{\bar{x}} / \mathrm{SD}$ & $\mathrm{Md} / \overline{\mathrm{IL}-4} \mathrm{x} / \mathrm{SD}$ & $\begin{array}{c}\mathrm{IL}-10 \\
\mathrm{Md} / \bar{x} / \mathrm{SD}\end{array}$ & \\
\hline $\mathrm{G}_{1}$ & 674 / 619 / 168 & 314 / 382 / 163 & $108 / 116 / 50$ & 46 / 49 / 16 & $51 / 56 / 15$ & Mature Th0 \\
\hline $\mathrm{G}_{2}$ & 404 / 463 / 186 & $531 / 555 / 199$ & $128 / 123 / 29$ & 40 / 47 / 17 & 42 / 50 / 22 & Mature Th0 \\
\hline $\mathrm{G}_{3}$ & 389 / 486 / 265 & $589 / 610 / 178$ & $124 / 120 / 32$ & 42 / 44 / 19 & 41 / 49 / 22 & Mature Th0 \\
\hline $\mathrm{G}_{4}$ & $97.5 / 98 / 25$ & 209 / 214 / 64 & 103.5 / 109 / 43 & $10 / 8 / 4$ & $9 / 8 / 6$ & Normal \\
\hline $\begin{array}{l}\text { Normal values } \\
(\bar{x} \mathrm{G} 4+1 \mathrm{SD})\end{array}$ & 123 & 278 & 152 & 12 & 14 & \\
\hline
\end{tabular}

G1:15 HIV-1 patients virgin to treatment; G2: 27 HIV-1 patients under HAART with detectable VL; G3: 31 HIV-1 patients under HAART with undetectable VL; G4: 20 normal blood donor volunteers; Md: median; $\bar{X}$ : mean; SD: standard deviation.

Table 3. Distribution of mononuclear cell cytokine values by group (RT-PCR)

\begin{tabular}{|c|c|c|c|c|c|c|}
\hline \multirow{2}{*}{ Groups } & \multicolumn{5}{|c|}{ Mononuclear cell cytokine (\% mRNA expression) } & \multirow{2}{*}{ Th subset } \\
\hline & $\begin{array}{c}\text { TNF- } \alpha \\
\mathrm{Md} / \bar{x} / \mathrm{SD}\end{array}$ & $\begin{array}{c}\mathrm{IFN}-\gamma \\
\mathrm{Md} / \bar{x} / \mathrm{SD}\end{array}$ & $\begin{array}{c}\mathrm{IL}-2 \\
\mathrm{Md} / \bar{x} / \mathrm{SD}\end{array}$ & $\operatorname{Md} / \frac{\mathrm{IL}-4}{\bar{x}} / \mathrm{SD}$ & $\begin{array}{c}\mathrm{IL}-10 \\
\mathrm{Md} / \bar{x} / \mathrm{SD}\end{array}$ & \\
\hline $\mathrm{G}_{1}$ & $62 / 58 / 18$ & $46 / 46 / 25$ & $47 / 47 / 17$ & 62 / 62 / 18 & 65 / 68 / 20 & Mature Th0 \\
\hline $\mathrm{G}_{2}$ & 49 / 50 / 21 & 66 / 62 / 25 & $56 / 56 / 16$ & $51 / 60 / 21$ & 55 / 64 / 25 & Mature Th0 \\
\hline $\mathrm{G}_{3}$ & 46 / 52 / 26 & $63 / 68 / 25$ & $48 / 50 / 15$ & $52 / 58 / 24$ & $70 / 67 / 25$ & Mature Th0 \\
\hline $\mathrm{G}_{4}$ & $-12 /-11 / 10$ & $-15.5 /-11 / 16$ & $-22 /-17 / 18$ & $-22 /-29 / 21$ & $-20.5 /-28 / 20$ & Normal \\
\hline $\begin{array}{l}\text { Normal values } \\
(\bar{x} \text { G4 + 1SD) }\end{array}$ & -1 & 5 & 1 & -8 & -8 & \\
\hline
\end{tabular}

G1:15 HIV-1 patients virgin to treatment; G2: 27 HIV-1 patients under HAART with detectable VL; G3: 31 HIV-1 patients under HAART with undetectable VL; G4: 20 normal blood donor volunteers; Md: median; $\bar{X}$ : mean; SD: standard deviation. 
D. A. Meira et al. ASSESSMENT OF CYTOKINE VALUES IN SERUM BY RT-PCR IN HIV-1 INFECTED INDIVIDUALS WITH AND WITHOUT HIGHLY ACTIVE ANTI-RETROVIRAL THERAPY (HAART). J. Venom. Anim. Toxins incl. Trop. Dis., 2008, 14, 4, p. 697

\section{Definition of Th-1, mature Th-0 and Th-2 subsets (22)}

Given that no normal standard exists for serum cytokine levels obtained by ELISA or for mononuclear cell cytokine by RT-PCR, there was a need to establish a normal value for each method. For this, 20 normal individuals - who had no clinical sign of the disease and were tested negative for HIV-1 infection - were recruited for $G_{4}$ group. To find normal values for each cytokine, means were calculated for this control group and were added to one standard deviation; this result was considered normal. Cytokine profiles were made by comparing normal values with those from $G_{1}$, $G_{2}$, and $G_{3}$ in each method (ELISA or RT-PCR). Results showed that mature Th-0 was the dominant profile in both serum levels (ELISA) and mononuclear cell determinations (RT-PCR) (Tables 2, 3 and 4).

Table 4. Serum and mononuclear cell cytokine subsets according to normal values, obtained by $\bar{X}+1 \mathrm{SD}$ of their respective normal group values $\left(\mathrm{G}_{4}\right)^{*}$

\begin{tabular}{|c|c|c|c|c|c|c|c|c|}
\hline \multirow{2}{*}{ Subset } & \multicolumn{2}{|c|}{ IFN- $\gamma$} & \multicolumn{2}{|c|}{ IL-2 } & \multicolumn{2}{|c|}{ IL-4 } & \multicolumn{2}{|c|}{ IL-10 } \\
\hline & $(\mathrm{pg} / \mathrm{mL})$ & (\% mRNA) & $(\mathrm{pg} / \mathrm{mL})$ & ( $\%$ mRNA) & $(\mathrm{pg} / \mathrm{mL})$ & (\% mRNA) & $(\mathrm{pg} / \mathrm{mL})$ & (\% mRNA) \\
\hline$\overline{\text { Th1 }}$ & $>278$ & $>5$ & $>152$ & $>1$ & $<12$ & $<-8$ & $<14$ & $<-8$ \\
\hline Mature Th0 & $>278$ & $>5$ & $\leq 152$ & $\leq 1$ & $>12$ & $>-8$ & $>14$ & $>-8$ \\
\hline Th2 & $<278$ & $<5$ & $<152$ & $<1$ & $>12$ & $>-8$ & $>14$ & $>-8$ \\
\hline
\end{tabular}

* Adapted from Spellberg and Edwards (22).

\section{DISCUSSION}

Cytokines levels obtained by ELISA in serum and by RT-PCR in mononuclear cells were compared among groups. This comparison revealed statistical significances for all cytokines, except for IL-2. It was the only cytokine that, although statistically significant, did not distinguished groups by ELISA in serum; this ascertaining drew attention to IL-2. In addition, normal individuals presented lower levels of cytokines by both methods, with the exception of IL-2 by ELISA. Furthermore, significance was found for all proteins by ELISA and RT-PCR in linear correlation. However, IL-2 significance level $(p)$ was lower. These findings suggest that similarity indeed exists between the two methods.

In an earlier publication, Meira et al. (15) exposed the serum cytokine behavior in a cross-sectional study, in which 79 HIV-1/AIDS patients were distributed into three 
D. A. Meira et al. ASSESSMENT OF CYTOKINE VALUES IN SERUM BY RT-PCR IN HIV-1 INFECTED INDIVIDUALS WITH AND WITHOUT HIGHLY ACTIVE ANTI-RETROVIRAL THERAPY (HAART). J. Venom. Anim. Toxins incl. Trop. Dis., 2008, 14, 4, p. 698

groups following the same criteria applied to the current study. They observed that no patient in any group had a Th-1 or a virgin Th-0 profile, because mature Th-0 predominated in all groups (22). Low proportions of Th-2 profile were also recorded in a few patients from each group. The absence of Th-1 and the presence of Th-2 profile in the three groups implied that there was no increase of IL-2 and INF- $\gamma$ in these patients, even after treatment. In the present study, IL-2 also showed positive correlation with INF- $\gamma$ and $C D 4^{+} \mathrm{T}$ cells and negative correlation with VL, TNF- $\alpha$, IL-4 and IL-10, supporting the proposal that IL-2 could be an important marker for immune recuperation in HIV-1 infections, along with VL and $C D 4^{+} \mathrm{T}$ determination. In this sense, only $\mathrm{CD} 4^{+} \mathrm{T}$ cell count without cytokine levels may hinder immune recovery interpretation under ARV treatment, as this process can increase these cell counts but without a corresponding rise in IL-2.

Jansen, Baarle and Miedema (12), regarding HIV-1 infection evolution, once asked: what is in control? Could it be HIV-specific $\mathrm{CD}^{+} \mathrm{T}$ cells? Or viremia (VL)? They reported that in infected individuals with increased VL, virgin and HIV-specific CD $4^{+} T$ memory cells are continually activated and preferentially induced to differentiate into INF- $\gamma$ producers (12), namely Tem2 cells (IL-2-INF- $\gamma^{+}$CD45RA ${ }^{-}$CCR7 ${ }^{-}$). The latter cells do not have the capacity to produce IL-2 and proliferate; they are only capable of producing INF- $\gamma$. The current study findings agree with these previous investigations $(12,25)$.

The interpretation of present results took into account the behaviors of IL-2 and INF$\gamma$, and, therefore, their repercussions on dominant Th profile. Additionally, it was necessary to consider that mean values of serum IL-2, obtained by ELISA, were lower than normal in the three patient groups. RT-PCR method, in turn, found low means that were statistically equal among groups, but a little higher than the control individuals. In contrast, INF- $\gamma$ mean values were always greater by both methods, more than twice the normal mean value. Consequently, mature Th-0 profile was predominant in $G_{1}, G_{2}$ and $G_{3}$ in both studied methods. This observation coincides with the analysis made by Jansen, Baarle and Miedema (12), in which virgin or HIVspecific $\mathrm{CD}^{+} \mathrm{T}$ memory cells are continually activated. Immune activation increases VL, causing a depletion in $C D 4^{+} T$ cells and, therefore, in AIDS (12). On one hand, these authors inferred the behavior of individuals with rapid progression from those with increased $\mathrm{VL}$, whose virgin or HIV-specific $\mathrm{CD} 4^{+} \mathrm{T}$ memory cells are continually 
D. A. Meira et al. ASSESSMENT OF CYTOKINE VALUES IN SERUM BY RT-PCR IN HIV-1 INFECTED INDIVIDUALS WITH AND WITHOUT HIGHLY ACTIVE ANTI-RETROVIRAL THERAPY (HAART). J. Venom. Anim. Toxins incl. Trop. Dis., 2008, 14, 4, p. 699

activated, inducing differentiation only into INF- $\gamma$ producers (IL-2 INF- $\gamma^{+}$CD45RA ${ }^{-}$ $\mathrm{CCR} 7^{-}$) (12). And, on the other hand, they deduced the behavior from long-term nonprogressors (LTNP) individuals, which present low viremia and their $C D 4^{+} T$ cells have an IL-2 ${ }^{+}$INF- $\gamma^{+}$CD45RA ${ }^{-} \mathrm{CCR} 7^{+}$phenotype producer. The $\mathrm{CD} 4^{+} \mathrm{T}$ cells $-\mathrm{IL}-2$ and both IL-2 and INF- $\gamma$ producers - are found in LTNP, but not in those with rapid progression (24).

Hel, McGhee and Mestecky (10), referring to the mystery of HIV progression, mentioned other agents like Mycobacterium tuberculosis, cytomegalovirus and the herpes viruses, as examples of pathogens that had afflicted humans in the distant past and had sufficient time to pass through mutual adaptations, both in the infection and immune processes. HIV-1, however, has been infecting humans for few decades and has not yet had enough time to develop these mutual adaptations. For this reason, the infection that causes AIDS is recently in a wild and aggressive phase. Quoting these authors (10): "There is an irrefutable proof of a drop in $\mathrm{CD}^{+} \mathrm{T}$ cells early in HIV-1 infection, mainly in lymphatic and intestine tissues". These cells are destructed by apoptosis, in which INF- $\alpha$ participates in the elimination of thymocytes. There are many mechanisms, induced by HIV, that lead to cell death, from the virus protease to IL-7 in the thymus including the syncytium formation (23).

$\mathrm{Hel}$, McGhee and Mestecky (10) mentioned that the eradication of initial viremia from HIV-1 infection by natural resistance, early in anti-retroviral treatment or even by the use of vaccines that can protect the $\mathrm{CD} 4^{+} \mathrm{T}$ memory, may result in immune recovery.

\section{CONCLUSIONS}

The results of the current study allow us to state that there is an association between the two methods employed to measure cytokine levels, except for IL-2 values. The different behaviors between ELISA and RT-PCR regarding this cytokine cannot be explained based on result analysis. Therefore, other studies are necessary to investigate this unexpected behavior.

Judging by the persistently low level of IL-2, even in individuals under HAART for several years and with undetectable viral load, these patients do not show any evidence of immune recuperation. 
D. A. Meira et al. ASSESSMENT OF CYTOKINE VALUES IN SERUM BY RT-PCR IN HIV-1 INFECTED INDIVIDUALS WITH AND WITHOUT HIGHLY ACTIVE ANTI-RETROVIRAL THERAPY (HAART). J. Venom. Anim. Toxins incl. Trop. Dis., 2008, 14, 4, p. 700

\section{ACKNOWLEDGMENTS}

This work was supported by the State of São Paulo Research Foundation (FAPESP), grant 01/14297-8.

\section{ETHICAL APPROVAL}

This study was approved by the Ethics Research Committee of Botucatu Medical School, São Paulo State University, UNESP, Botucatu, São Paulo State, Brazil.

\section{REFERENCES}

1 BOYUM A. Separation of leukocytes from blood and bone marrow. Introduction. Scan. J. Clin. Lab. Invest. Suppl., 1968, 97, 7.

2 CARCELAIN G., LI T., RENAUD M., DEBRE P., AUTRAN B. Immune reconstitution of the CD4 ${ }^{+}$T-Cell compartment in HIV infection. In: COSSARIZZA A., KAPLAN D. (Eds.) Cellular aspects of HIV infection. New York: Willey-Liss Inc., 2002. p. 399-422.

3 CLERICI M., SHEARER GM. A TH-1/TH-2 switch is a critical step in etiology of HIV infection. Immunol. Today, 1993, 14, 107-11.

4 CLERICI M., BALOTTA C., SALVAGGIO A., RIVA C., TRABATTONI D., PAPAGNO L., BERLUSCONI A., RUSCONI S., VILLA ML., MORONI N., GALLI M. Human immunodeficiency virus (HIV) phenotype and interleukin-2/interleukin-10 ratio are associated markers of protection and progression in HIV infection. Blood, 1996, $88,574-9$.

5 CLERICI M., GALLI M., BOSIS S., GERVASONI C., MORONI M., NORBIATO G. Immunoendocrinologic abnormalities in human immunodeficiency virus infection. Ann. N. Y. Acad. Sci., 2000, 917, 956-61.

6 GERLI R., LUNARDI C., VINANTE F., BISTONI O., PIZZOLO G., PITZALIS C. Role of CD30+ $T$ cells in rheumatoid arthritis: a counter-regulatory paradigm for Th1driven diseases. Trends Immunol., 2001, 22, 72-7.

7 GOUGEON ML., LOECOUER H., PINTO LMO., LEDRU E. Homeostasis and restoration of the immune system in HAART-treated HIV-infected patients: implication of apoptosis. In: COSSARIZZA A., KAPLAN D. (Eds.) Cellular aspects of HIV infection. New York: Willey-Liss Inc., 2002. 251-68p. 
D. A. Meira et al. ASSESSMENT OF CYTOKINE VALUES IN SERUM BY RT-PCR IN HIV-1 INFECTED INDIVIDUALS WITH AND WITHOUT HIGHLY ACTIVE ANTI-RETROVIRAL THERAPY (HAART). J. Venom. Anim. Toxins incl. Trop. Dis., 2008, 14, 4, p. 701

8 GREWE M., BRUIJNZEEL-KOOMEN CA., SCHÖPF E., THEPEN T., LANGEVELD-WILDSCHUT AG., RUZICKA T., KRUTMANN J. A hole for Th1 and Th2 in the immunopathogenesis of atopic dermatitis. Immunol. Today, 1998, 19, 35961.

9 HAASE AT. Population biology of HIV-1 infection: viral and $\mathrm{CD}^{+} \mathrm{T}$ cell demographics and dynamics in lymphatic tissues. Annu. Rev. Immunol., 1999, 17, 625-56.

10 HEL Z., MCGHEE JR., MESTECKY J. HIV infection: first battle decides the war. Trends Immunol., 2006, 27, 274-81.

11 IMAMI N., ANTONOPOULOS C., HARDY GA., GAZZARD B., GOTCH FM. Assessment of type 1 and type 2 cytokines in HIV type 1-infected individuals: impact of highly active antiretroviral therapy. AIDS Res. Hum. Retroviruses, 1999, 15, 1499508.

12 JANSEN CA., VAN BAARLE D., MIEDEMA F. HIV-specific CD4 ${ }^{+} \mathrm{T}$ cells and viremia: who's in control? Trends Immunol., 2006, 27, 119-24.

13 KAMPMANN B., TENA-COKI GN., NICOL MP., LEVIN M., ELEY B. Reconstitution of antimycobacterial immune responses in HIV-infected children receiving HAART. AIDS, 2006, 20, 1011-18.

14 MEIRA DA., ANTUNES MC., SOUZA LR., MARCONDES-MACHADO J., CALVI SA., LIMA CRG., HENRIQUES RMS., PARDINI MI., SILVA VA., IUAN FC., CURI PR. Nível sérico de citocinas como indicadores de fase evolutiva em indivíduos com infecção pelo HIV-1, doentes ou não. J. Bras. AIDS, 2000, 1, 17-27.

15 MEIRA DA., SOUZA LR., CALVI SA., LIMA CRG., HENRIQUES RMS., PARDINI Ml., SILVA VA., IUAN FC., MARCONDES-MACHADO J. Correlation between cytokine serum levels, number of $\mathrm{CD} 4^{+} \mathrm{T}$ cells $/ \mathrm{mm}^{3}$ and viral load in HIV-1 infected individuals with or without antiretroviral therapy. J. Venom. Anim. Toxins incl. Trop. Dis., 2004, 10, 293-310.

16 MELLORS JW., RINALDO JR CR., GUPTA P., WHITE RM., TODD JA., KINGSLEY LA. Prognosis in HIV-1 infection predicted by the quantity of virus in plasma. Science, 1996, 272, 1167-70.

17 MOSMANN TR. Cytokine patterns during the progression to AIDS. Science, 1994, 265, 193-4. 
D. A. Meira et al. ASSESSMENT OF CYTOKINE VALUES IN SERUM BY RT-PCR IN HIV-1 INFECTED INDIVIDUALS WITH AND WITHOUT HIGHLY ACTIVE ANTI-RETROVIRAL THERAPY (HAART). J. Venom. Anim. Toxins incl. Trop. Dis., 2008, 14, 4, p. 702

18 PEETERS D., PETERS IR., CLERCX C., DAY MJ. Real-time RT-PCR quantification of mRNA encoding cytokines, CC chemokines and CCR3 in bronchial biopsies from dogs with eosinophilic broncopneumopathy. Vet. Immunol. Immunopathol., 2006, 110, 65-77.

19 PERUSSIA B., LOZA MJ. Linear "2-0-1" lymphocyte development: hypotheses on cellular bases for immunity. Trends Immunol., 2003, 24, 235-41.

20 PIERSON T., MCARTHUR J., SILICIANO RF. Reservoirs for HIV-1: mechanisms for viral persistence in the presence of antiviral immune responses and antiretroviral therapy. Annu. Rev. Immunol., 2000, 18, 665-708.

21 PLATZER C., BLANKENSTEIN T. Polymerase chain reaction to quantitative cytokine mRNA. In: BALKWILL FR. (Ed.) Cytokines: a practical approach. Oxford: Oxford University Press, 1995. p. 57-75.

22 SPELLBERG B., EDWARDS JR JE. Type-1/Type-2 immunity in infectious diseases. Clin. Infect. Dis., 2001, 32, 76-102.

23 VRISEKOOP N., HAZENBERG MD., MIEDEMA F., BORGHANS JAM. T cell dynamics and the role of apoptosis in HIV infection. In: BADLEY AD. (Ed.) Cell death in HIV infection. Florida: CRC Press, 2006. p. 319-34.

24 WILSON JD., IMAMI N., WATKINS A., GILL J., HAY P., GAZZARD B., WESTBY M., GOTCH FM. Loss of $\mathrm{CD}^{+} \mathrm{T}$ cell proliferative ability but not loss of human immunodeficiency virus type 1 specificity equates with progression to disease. J. Infect. Dis., 2000, 182, 792-8.

25 YOUNES SA., YASSINE-DIAB B., DUMONT AR., BOULASSEL MR., GROSSMAN Z., ROUTY JP., SEKALY RP. HIV-1 viremia prevents the establishment of interleukin 2-producing HIV-specific memory $\mathrm{CD}^{+} \mathrm{T}$ cells endowed with proliferative capacity. J. Exp. Med., 2003, 198, 1909-22.

26 ZAR JH. Biostatistical analysis. 3.ed. New Jersey: Prantice-Hall Inc., 1996, 662p. 